\title{
Retinoid-dependent in vitro transcription mediated by the RXR/RAR heterodimer
}

\author{
Rafael Valcárcel, Herbert Holz, Custodia García Jiménez, Domingo Barettino, \\ and Hendrik G. Stunnenberg ${ }^{1}$ \\ European Molecular Biology Laboratory (EMBL), Gene Expression Program, D-69117 Heidelberg, Germany
}

\begin{abstract}
The effects of retinoids on gene regulation are mediated by retinoic acid receptors (RARs) and retinoid $X$ receptors (RXRs). Here, we provide the first biochemical evidence that, in vitro, ligand governs the transcriptional activity of $R X R \alpha / R A R \alpha$ by inducing conformational changes in the ligand-binding domains. Using limited proteolytic digestion we show that binding of the cognate ligand causes a conformational change in the carboxy-terminal part of the receptor. We also show that recombinant RXR $\alpha / R A R \alpha$ is partially active in the absence of exogenously added ligand. Trans-activation depends critically on the ligand-dependent transcriptional activation function AF-2 of RAR $\alpha$. Full activation by recombinant RXR $\alpha / R A R \alpha$, however, requires the addition of either all-trans RA, 9-cis RA, or other RAR-specific agonists, whereas an RAR $\alpha$-specific antagonist abolishes trans-activation. Intriguingly, the ligand-dependent AF-2 of RXR does not contribute to the level of transcription from the $R A R \beta_{2}$ promoter in vitro even when the cognate ligand (9-cis RA) is bound. Thus, the major role of RXR in trans-activation of the RAR $\beta_{2}$ promoter is to serve as an auxiliary factor required for the binding of RAR which, in turn, is directly responsible for transcriptional activity.
\end{abstract}

[Key Words: RXR/RAR heterodimer; gene regulation; trans-activation; RAR-specific agonists]

Received June 2, 1994; revised version accepted October 21, 1994.

Retinoids play an important role in development, differentiation, and homeostasis (De Luca 1991; Leid et al. 1992a). Two classes of nuclear retinoid-binding proteins have been implicated: retinoic acid and retinoid $X$ receptors (RAR and RXR, respectively), which belong to the nuclear receptor superfamily of ligand-inducible transcription factors. RAR and RXR /each consisting of three subtypes $\alpha, \beta$, and $\gamma$ ) belong to the type II subfamily, which includes the receptors for thyroid hormone $\left(T_{3} R\right)_{\text {, }}$ vitamin $D_{3}\left(V D_{3} R\right)$, and the peroxisome proliferator-activated receptor (PPAR) (for review, see Stunnenberg 1993). With the possible exception of RXR, type II receptors do not bind to their cognate binding sites as homodimers but require RXR for high-affinity binding (Yu et al. 1991; Bugge et al. 1992; Kliewer et al. 1992a, b; Leid et al. 1992b; Marks et al. 1992; Zhang et al. 1992!. Type II receptors activate transcription through binding sites composed of closely related motifs arranged as direct repeats spaced by $1-5$ nucleotides, termed $D R+1$ to $\mathrm{DR}+5$ elements. RXR/RAR bind and trans-activate preferentially through $\mathrm{DR}+5, \mathrm{DR}+2$ and, to a much lesser extent, DR +1 elements (for review, see Leid et al. 1992a; Stunnenberg 1993, and references therein). RXR homodimers have been reported to bind and trans-activate through the $D R+1$ element (Mangelsdorf et al. 1991; Zhang et al. 1992).

\footnotetext{
${ }^{1}$ Corresponding author.
}

Similar to other members of the nuclear receptor superfamily, RAR and RXR exhibit a modular structure composed of three distinct domains: an amino-terminal domain containing a constitutive trans-activation function (AF-1) (Folkers et al. 1993; Nagpal et al. 1993), a central DNA-binding domain that also encompasses determinants for polarity in binding of the heterodimer to direct repeat elements (Kurokawa et al. 1993; Perlmann et al. 1993; Zechel et al. 1994a, bl, and a carboxy-terminal domain comprising a ligand-binding dimerization and ligand-dependent trans-activation function (AF-2) (for review, see Leid et al. 1992a, Stunnenberg 1993). The relative contributions of the individual AFs of RAR and RXR in trans-activation vary according to the nature of the RA response element (RARE) and its promoter context (Durand et al. 1992; Nagpal et al. 1992).

The transcriptional activity of the ligand-dependent AF-2 in the carboxy-terminal part of RAR and RXR is thought to be governed by the ligand. All-trans and 9-cis retinoic acid (T-RA and 9C-RA) bind to RAR and induce a conformational change in its ligand-binding domain (LBD), whereas RXR only binds 9C-RA (Heyman et al. 1992; Levin et al. 1992) and likewise induces a conformational change (this study; Keidel et al. 1994; Leid 1994). An RAR $\alpha$-specific antagonist has been shown to induce a conformational change in RAR $\alpha$ (Keidel et al. 1994) different from that obtained with agonist, probably resulting in an impaired ability of the antagonist-loaded 
receptor to interact with other molecules, such as cofactors or components of the basal transcription machinery.

The dissection of regulatory circuits by cotransfer experiments is complicated by the presence of multiple retinoid receptor isoforms (Leid et al. 1992a), some of which appear to be expressed ubiquitously, and the utilization of different response elements. Furthermore, RXR can heterodimerize with a number of different receptors other than RAR, such as $T_{3} R, V_{3} R$, and PPAR, and as such can bind and trans-activate through response elements that are identical or very similar to RAREs. Finally, there is a high degree of redundancy in the retinoid signaling pathway, as revealed by gene-targeting experiments (Chambon 1994). Hence, it is extremely difficult to attribute a particular effect to a distinct receptor isoform.

Therefore, a ligand-dependent in vitro transcription assay would be extremely useful, not only in studying the molecular mechanisms underlying ligand-induced transactivation but also in identifying cofactors that are required for gene activation. Here, we describe an in vitro transcription system that supports retinoid-dependent trans-activation from a promoter fragment derived from the human $R A R \beta_{2}$ gene. In vivo, the expression of this gene is up-regulated in response to RA through a RARE $(\mathrm{DR}+5)$ located in close proximity to the TATA box (De Thé et al. 1990; Sucov et al. 1990; Vivanco Ruiz et al. 1991). We have assessed the trans-activating abilities of recombinant $\operatorname{RAR} \alpha$ and $\mathrm{RXR} \alpha$ coexpressed and copurified as a heterodimer. Finally, we have analyzed the effects of various retinoids and synthetic agonists and antagonists in this trans-activation assay.

\section{Results}

\section{Expression and purification of $R A R \alpha$ and $R X R \alpha$}

Human RAR $\alpha$ and RXR $\alpha$ and truncated versions thereof were expressed in HeLa cells using recombinant vaccinia virus encoding either the authentic receptor or a fusion protein containing a stretch of six histidines fused to the amino terminus (abbreviated $6 \mathrm{H}$ ). $\mathrm{RXR} \alpha / 6 \mathrm{H}-\mathrm{RAR} \alpha$ heterodimer prepared from HeLa cells infected with a mixture of two vinuses was purified through $\mathrm{Ni}^{2+}-\mathrm{NTA}$ column chromatography as described (Janknecht et al. 1991; Schmitt et al. 1993). The receptor purifications were analyzed by silver staining, Western blot analysis, and bandshift assays. Shown in Figure 1 is a silver-staining and Western blot analysis of $\mathrm{RXR} \alpha / 6 \mathrm{H} \cdot \mathrm{RAR} \alpha$ purified over $\mathrm{Ni}^{2+}$-NTA. $6 \mathrm{H}-\mathrm{RAR} \alpha$ and $\mathrm{RXR} \alpha$ are present in roughly stoichiometric amounts in the heterodimer preparation, as revealed by bandshift analysis using a $\mathrm{RARE}_{2}$ oligonucleotide (data not shown). The polyclonal antibodies were raised against the $\mathrm{D}$ and $\mathrm{E}$ domains of $\operatorname{RAR} \alpha$ and $\operatorname{RXR} \alpha$ expressed in Escherichia coli. The two polypeptides revealed by the RAR-specific antibody (Fig. 1, lanes 6,7) represent different phosphorylation forms of $6 \mathrm{H}-\mathrm{RAR} \alpha$ /C.G. Jiménez and G. de Martinoff, unpubl.).

\section{Ligand induces a conformational change in $R A R \alpha$ and $R X R \alpha$}

To analyze the ligand-binding properties of vaccinia virus-expressed $R A R \alpha$ and $R X R \alpha$, we performed protease clipping experiments. Binding of the cognate ligand induces a conformational change in the LBD that can be monitored by limited protease digestion (Allan et al. 1992; Keidel et al. 1994|. The proteolytic fragmentation patterns of NTA-purified receptors were revealed by Western blotting using polyclonal antibodies raised against the respective LBDs. Digestion of coexpressed and copurified RXR $\alpha / 6 \mathrm{H}-\mathrm{RAR} \alpha$ (Fig. 2A, lanes 2-6) or $6 \mathrm{H}-\mathrm{RAR} \alpha$ alone (data not shown) yielded a small amount of an $\sim 30-\mathrm{kD}$ RAR $\alpha$-derived polypeptide that is resistant to trypsin digestion in the absence of exogenously added ligand. This trypsin-resistant fragment could not be de-

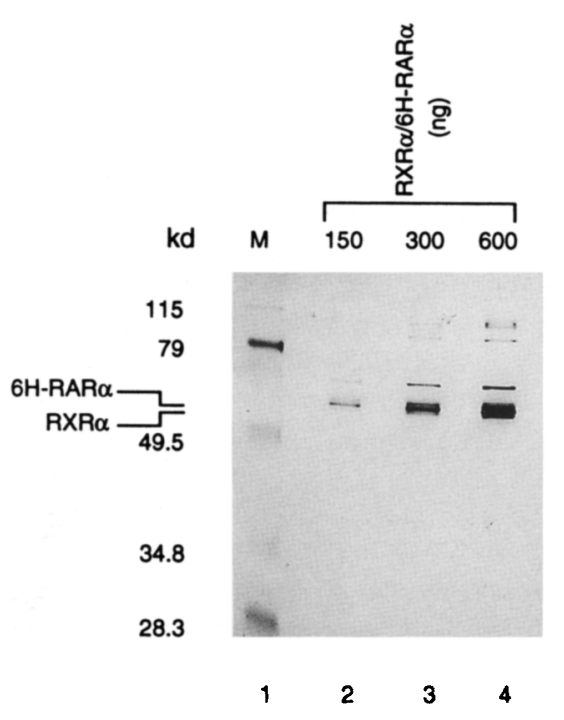

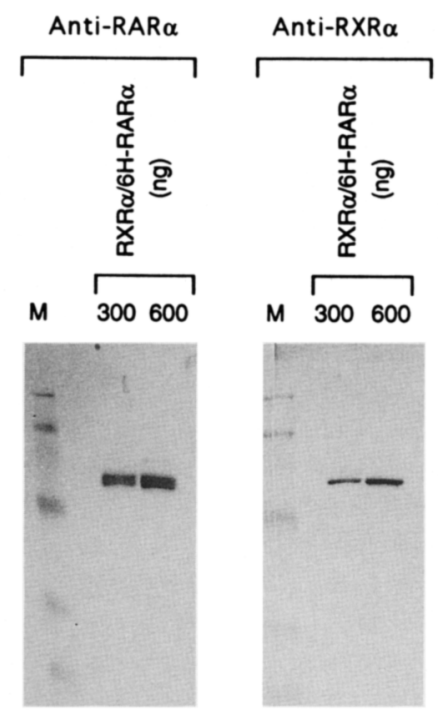

8

910
Figure 1. Analysis of the $\mathrm{Ni}^{2+}-\mathrm{NTA}$-purified RXR $\alpha / 6$ H-RAR $\alpha$. Silver staining (lanes 1-4) and Western blot analysis (lanes 5-10) of the $\mathrm{Ni}^{2+}$ NTA purified heterodimer are shown. (Lanes $1,5,8$ ) Molecular mass markers (M). The positions at which $\mathrm{RXR} \alpha$ and $6 \mathrm{H} \cdot \mathrm{RAR} \alpha$ migrate and the molecular mass of the markers are indicated. The amount of heterodimer is indicated in nanograms. Lanes 5-7 were developed with an RAR $\alpha$ antibody (raised against the RAR $\alpha \mathrm{DE}$ domain); lanes 8-10 were developed with an $\mathrm{RXR} \alpha$ antibody (raised against the RXR $\alpha$ DE domain), using alkaline phosphatase-linked anti-rabbit inmunoglobulin as the second antibody. 


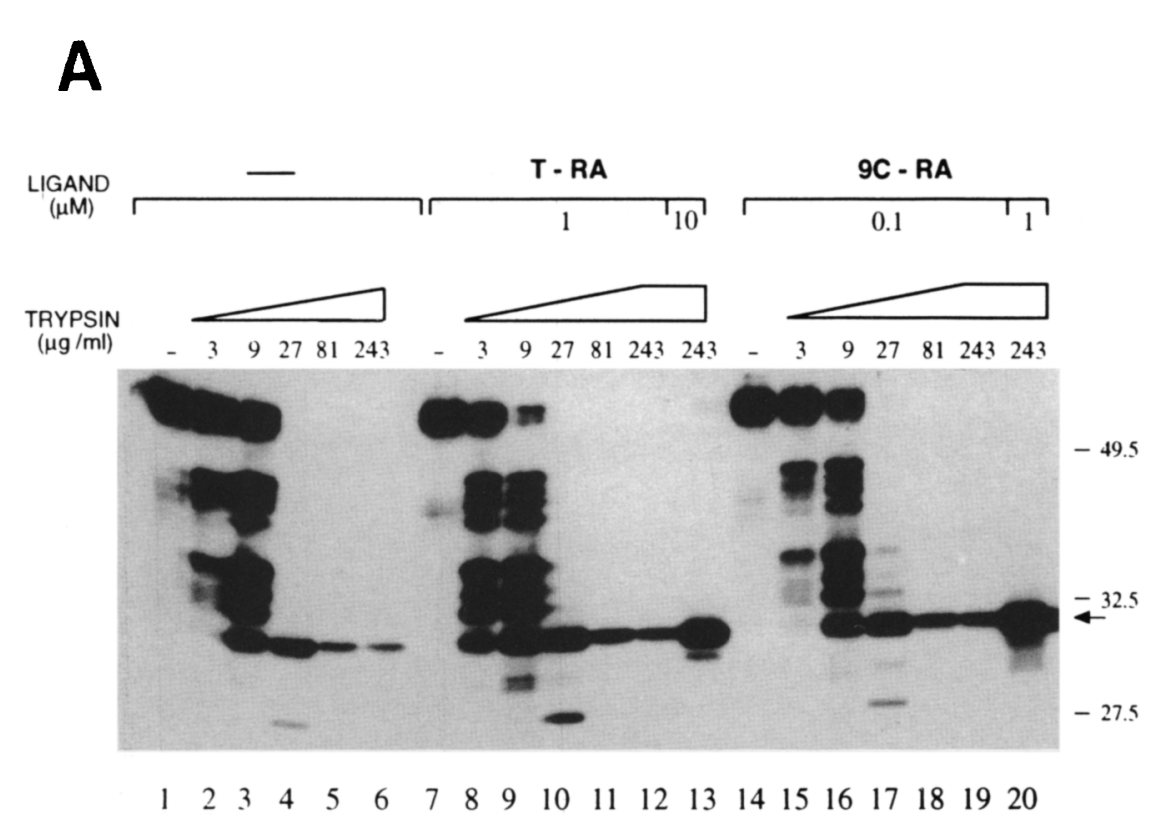

B

Figure 2. Retinoids induce a conformational change in the ligand-binding domain of RAR $\alpha$ and RXR $\alpha$. The amount of heterodimer used was $1.2 \mu \mathrm{g} /$ reaction. The amount of trypsin $(\mu \mathrm{g} / \mathrm{ml})$ and the concentration of the ligands $(\mu \mathrm{M})$ are indicated. The sizes of molecular mass markers are indicated at right. $|A| \mathrm{RXR} \alpha / 6 \mathrm{H}-\mathrm{RAR} \alpha$ was incubated with trypsin at the indicated concentrations, in the presence of T-RA, 9C-RA, or solvent alone ( $2.5 \%$ ethanol), and the proteolytic products were analyzed by Western blotting with a polyclonal antibody raised against the ligand-binding domain of RAR $\alpha$. The peptide resistant to trypsin cleavage is indicated with an arrow. $(B) 6 \mathrm{H} \cdot \mathrm{RXR} \alpha$ was incubated with trypsin in the presence of $9 \mathrm{C} \cdot \mathrm{RA}$ or solvent alone $(2.5 \% \mathrm{DMSO})$, and the proteolytic products were analyzed by Western blotting with a polyclonal antibody raised against the ligand-binding domain of RXR $\alpha$. The bracket at right indicates resistant peptides.

tected with RXR $\alpha / 6 \mathrm{H}-\mathrm{RAR} \alpha$ or $6 \mathrm{H}-\mathrm{RAR} \alpha$ produced in reticulocyte lysates in the absence of ligand (Keidel et al. 1994; data not shown). Addition of increasing amounts of either T-RA or 9C-RA resulted in proportional increases in the amount of the $30-\mathrm{kD}$ polypeptide refractory to trypsin digestion (Fig. 2A, lanes 8-13, 15-20). Virtually quantitative protection could be obtained at 10 $\mu \mathrm{M}$ T-RA and $1 \mu \mathrm{M}$ 9C-RA (Fig. 2A, cf. lanes 7 and 14 with lanes 13 and 20 ).

Vaccinia virus-expressed $6 \mathrm{H}-\mathrm{RXR} \alpha$ was sensitive to trypsin digestion in the absence of $9 \mathrm{C}-\mathrm{RA}$ or in the presence of T-RA (Fig. 2B, lanes 1-3; data not shown) but refractory to digestion in the presence $9 \mathrm{C}-\mathrm{RA}$. A number of resistant polypeptides ranging in molecular mass between 27 and $35 \mathrm{kD}$ (Fig. 2B, lanes 4-6) could be detected. However, RXR $\alpha$ produced in reticulocyte lysates is refractory to trypsin digestion even in the absence of ligand (Keidel et al. 1994; Leid 1994). Chymotrypsin digestion of vaccinia virus-expressed RXR $\alpha / 6 \mathrm{H}-\mathrm{RAR} \alpha$ or $6 \mathrm{H} \cdot \mathrm{RXR} \alpha$ alone yielded results similar to those reported previously using RXR $\alpha$ produced in reticulocyte lysates, that is, RXR $\alpha$ became refractory to protease digestion proportional to the amount of added ligand reaching maximum levels at $1 \mu \mathrm{M}$ 9C-RA (Keidel et al. 1994; data not shown). In contrast, a recent study reported that the 9C-RA-induced conformational changes of in vitrotranslated RXR $\alpha$ could not be monitored with chymotrypsin but only with subtilisin (Leid 1994).
We conclude that vaccinia virus-expressed 6H-RAR $\alpha$ as well as $6 \mathrm{H}-\mathrm{RXR} \alpha$ are able to bind T-RA (RAR) and 9C-RA (RAR and RXR) because they undergo ligand-dependent conformational changes. Our data also show that a small percentage of recombinant $\operatorname{RAR} \alpha$ had already undergone this conformational change.

\section{$R X R / R A R$-dependent transcription}

The natural, RA-responsive RAR $\beta_{2}$ promoter from -124 to -21 , including the RARE and the TATA-box (De The et al. 1990) fused to a G-less cassette of 380 nucleotides, was used as the reporter (Berkenstam et al. 1992). As an internal control, a template comprising the adenovirus major late TATA box initiator fused to a G-less cassette of 320 nucleotides (TI) (Pugh and Tjian 1990) was used. After completion of the transcription reaction a labeled DNA fragment was added to monitor the recovery during sample preparation. These controls, internal control plasmid and recovery spike, allow us to draw conclusions from the results of an experiment without having to rely on cross-experiment comparisons. Addition of increasing amounts of coexpressed and copurified RXR $\alpha$ / $6 \mathrm{H}-\mathrm{RAR} \alpha$ resulted in a $>10$-fold enhancement of the level of transcription from the $R A R \beta_{2}$ reporter, without affecting transcription from the TI template (Fig. 3A). The enhancement in the level of transcription was not attributable to contamination in the receptor prepara- 
A

RXR $\alpha / 6 H-R A R \alpha$

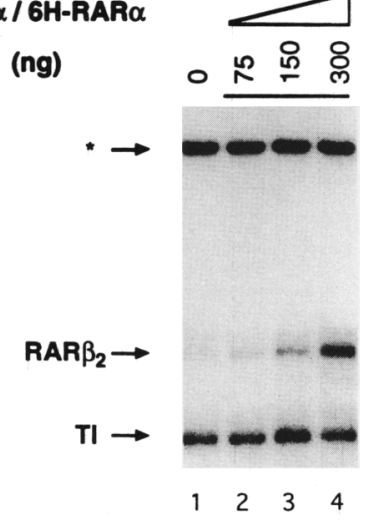

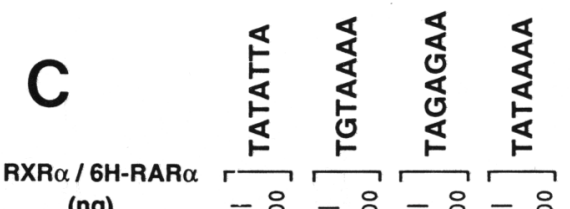

(ng)

- :

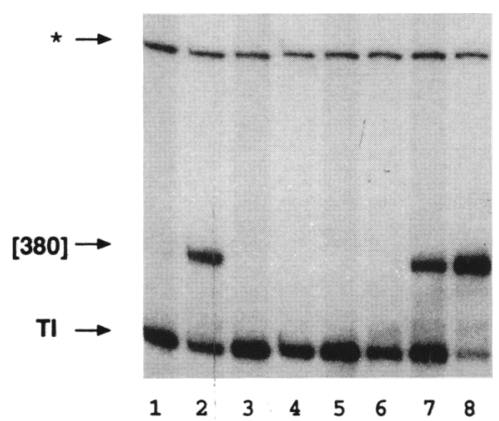

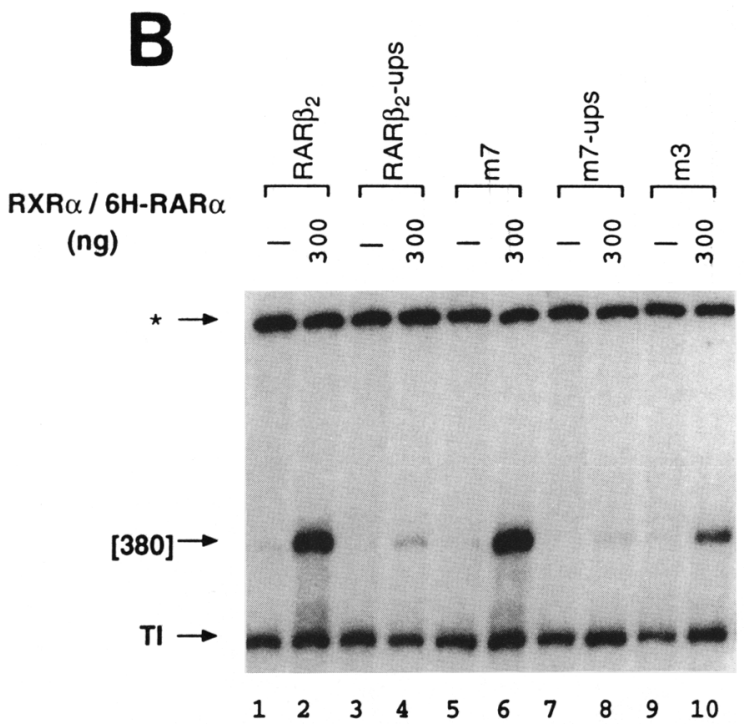
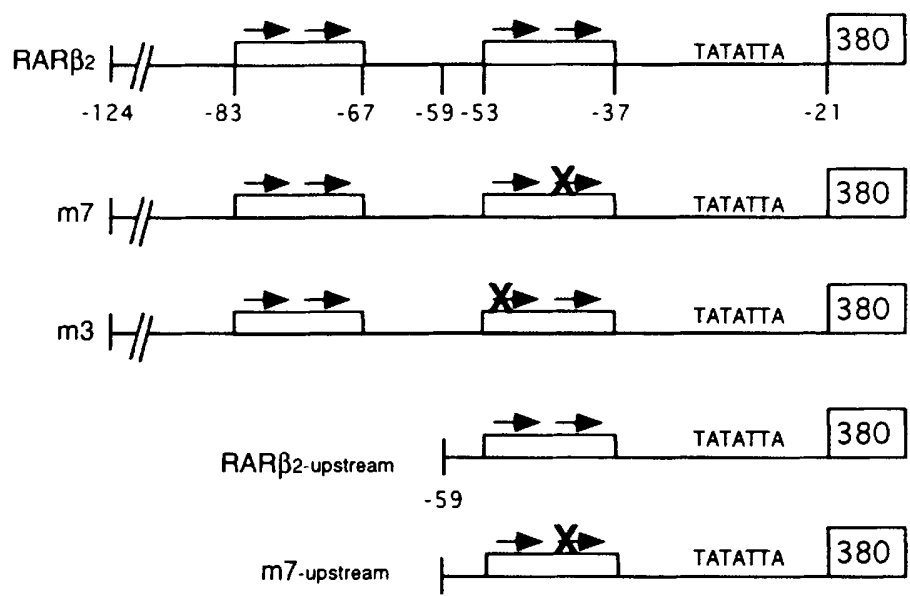

Figure 3. $\mathrm{RXR} \alpha / 6 \mathrm{H}-\mathrm{RAR} \alpha$-dependent trans-activation in vitro. The amount of heterodimer is indicated in nanograms. TI and $\mathrm{RAR} \beta_{2}$ indicate the positions of transcripts from the internal control and test template, respectively. Fifty ng of TI and $25 \mathrm{ng}$ of RAR $\beta_{2}$ plasmid were used per reaction. The recovery control is marked with an asterisk $(*|| A \mid$. Addition of the NTA-purified heterodimer enhances the level of transcription in vitro. $(B)$ Trans-activation is RARE dependent. A schematic diagram of the different test templates is shown. $(C)$ Effect of different TATA box mutations on the level of receptor-dependent trans-activation.

tion because control extracts derived from wild-type vaccinia virus-infected or mock-infected cells did not boost the level of transcription, either from the RAR $\beta_{2}$ promoter or from the TI template (data not shown).

To analyze whether the receptor-dependent trans-activation was mediated by the RARE, a minimal promoter fragment spanning the region from -59 to -21 , containing only the consensus RARE and TATA box, was constructed. This minimal promoter mediated RXR/RARdependent trans-activation, albeit at a reduced level (Fig. 3B, cf. lanes 2 and 4). Mutations introduced in either one of the consensus half-site motifs in the context of this minimal promoter fragment (m7-ups and m3-ups) reduced the RXR/RAR-dependent trans-activation even further (Fig. 3B, lane 8; data not shown). In the context of the longer promoter fragment a mutation introduced in the proposed RAR-specific half-site (Perlmann et al. 1993; Zechel et al. 1994a,b) of the consensus RARE at position -53 to -37 (reporter $\mathrm{m} 7$ ) did not affect the level of transcription. Introducing a mutation in the RXR-specific half-site (reporter $\mathrm{m} 3$ ) caused a diminution but not abolition of the level of transcription (Fig. 3B, cf. lanes 2, 6, and 10). Inspection of the DNA sequence revealed a potential, nonconsensus RARE located farther upstream (position -83 to -67 ). Mutations introduced into either one or both of the half-sites of this upstream potential RARE reduced the level of transcription to that obtained with the minimal promoter fragment, indicating that this imperfect RARE contributed to, but was not essential for, RXR/RAR-dependent transcription in vitro 
(data not shown). Transient transfection experiments showed that this element was not essential for, but potentiated, the RA response, and it was demonstrated to bind $\mathrm{RXR} \alpha / \mathrm{RAR} \alpha$ in vitro (B. Leblanc and H.G. Stunnenberg, in prep.).

We also tested the importance of the TATA box in receptor-dependent in vitro transcription. Mutations in the wild-type RAR $\beta_{2}$ TATA box -TATATTA- that are known to abolish or diminish TBP/TFIID binding, namely -TGTAAAA- (Strubin and Struhl 1992) and -TAGAGAA- (Berkenstam et al. 1992), abolished in vitro transcription (Fig. 3C, lanes 3-6). Replacement of the RAR $\beta_{2}$ TATA box with the TATA box from the adenovirus major late promoter (AdMLP) -TATAAAA- resulted in a marked increase in the basal level of transcription, whereas receptor-dependent enhancement of transcription was minimal (Fig. 3C, lanes 7,8). We surmise that in vitro binding of TFIID to the strong AdMLP TATA box is sufficient to yield high levels of transcription. In contrast, binding of the receptor is required for efficient preinitiation complex formation on the RAR $\beta_{2}$ TATA box both in vitro (Fig. 3) and in vivo (Berkenstam et al. 1992). Taken together, these experiments document bona fide receptor-dependent trans-activation from the $\mathrm{RAR}_{2}$ promoter.

\section{The ligand-dependent AF-2 of RAR $\alpha$ is essential for trans-activation}

The above documented activation of transcription by the heterodimer was obtained in the absence of exogenously added ligands. This raised the possibility that the enhancement of the level of transcription was attributable to the constitutive, ligand-independent amino-terminal AF-1 of RAR and/or RXR. Therefore, RXR $\alpha$ and RAR $\alpha$ mutants with truncated carboxy-terminal domains that abolish ligand binding were generated to assess whether the observed trans-activation was mediated by the AFl or AF-2, or both (Fig. 4). Full-length RXR $\alpha$ coexpressed and copurified with $6 \mathrm{H}-\mathrm{RAR} \alpha$ truncated at amino acid position 419 deleting the F-domain (6H-RAR 4419 ), resulted in a level of transcription comparable to RXR $\alpha$ / 6H-RAR $\alpha$ (Fig. 4, cf. lanes 2 and 3). However, a RAR $\alpha$ truncation up to position 390 (6H-RAR $\alpha 390$ ) deleting the putative AF-2 completely abolished trans-activation (lane 4). In contrast, deleting the putative AF-2 of RXR $\alpha$ (RXR $\alpha 445$ ) had no effect on the level of transcription (cf. lanes 2 and 5). Bandshift assays revealed that the truncated receptors were not affected in their ability to bind to the RARE $\beta_{2}$ (data not shown). Thus, the ligand-dependent trans-activation domain of RAR $\alpha$, but not RXR $\alpha$, is essential for trans-activation of the $\mathrm{RAR}_{2}$ promoter in vitro.

\section{Ligand-dependent activation}

The above results demonstrate that the ligand-dependent AF- 2 of RAR $\alpha$ is required for trans-activation and that recombinant $6 \mathrm{H}-\mathrm{RAR} \alpha$ and $6 \mathrm{H}-\mathrm{RXR} \alpha$ are able to bind their cognate ligand. The experiments depicted in Figure 2 showed that a small proportion of vaccinia virus-expressed RAR $\alpha$ was resistant to limited proteolytic digestion, suggesting that this receptor subpopulation had already undergone the conformational change and, consequently, may have been active transcriptionally. Therefore, we undertook experiments to determine whether we could either reverse the activated state or load the remainder presumably unliganded, inactive receptor population with ligand in vitro. NTA-purified $\mathrm{RXR} \alpha / 6 \mathrm{H}-\mathrm{RAR} \alpha$ was incubated in the presence of solvent or ligand at room temperature, and subsequently, the pretreated heterodimer was added to the transcription reaction. Pretreatment of the heterodimer in the presence of $10 \mu \mathrm{M}$ T-RA strongly boosted the level of
Figure 4. Receptor domain requirements for trans-activation in vitro. A schematic diagram of the RXR $\alpha$ and RAR $\alpha$ deletion mutants is shown. DNA affinity-purified receptors were used in this assay (see Materials and methods). The amount of heterodimer added to the reactions was normalized by Western blotting and bandshift assays, and $200 \mathrm{ng}$ of heterodimer was added to each reaction. Amounts of template were $10 \mathrm{ng}$ of $T I$ and $25 \mathrm{ng}$ of $\mathrm{RAR}_{2}$ per reaction.

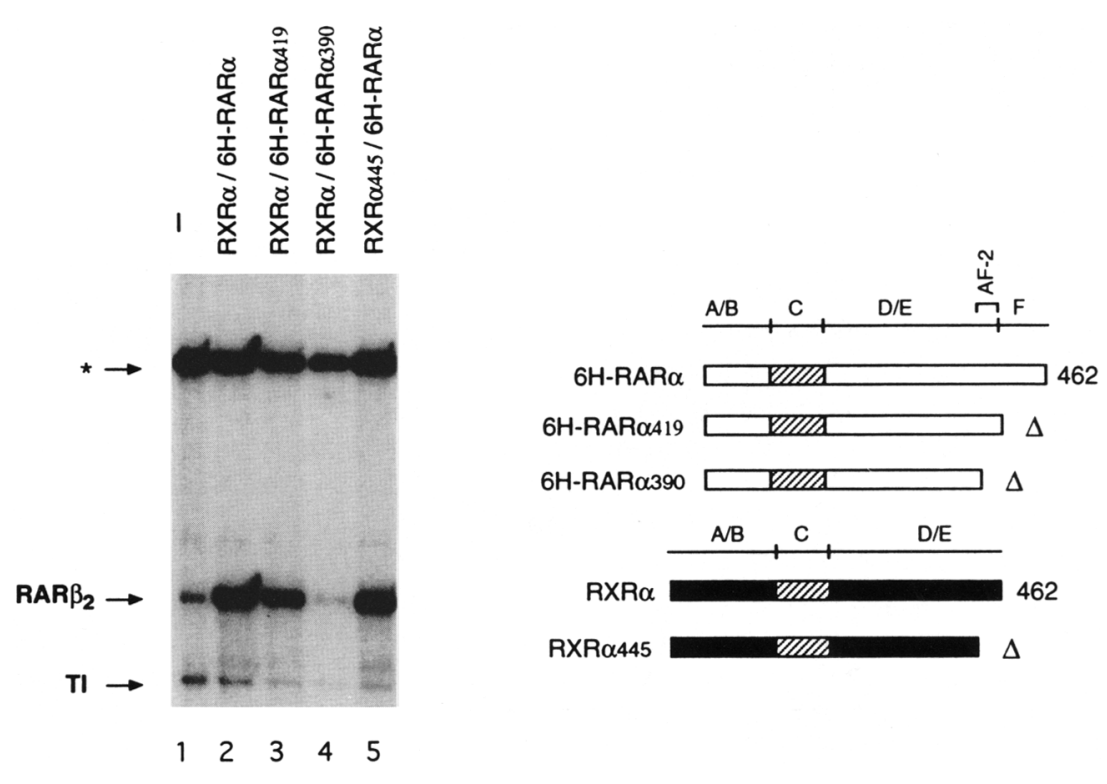


transcription as compared with untreated heterodimer or pretreated in the presence of $10 \%$ dimethylsulfoxide (DMSO) (Fig. 5A, cf. lanes 1-6 with 7-9). Bandshift assays revealed that the ligand or solvent pretreatment did not affect the ability of the heterodimer to bind the RARE $\beta_{2}$ oligonucleotide (Fig. 5B). We conclude from this that T-RA governs the transcriptional activity of RXR $\alpha$ / $6 \mathrm{H}-\mathrm{RAR} \alpha$.

The experiments described above (see Fig. 4) suggest that only the ligand-dependent AF-2 domain of RAR $\alpha$ is required for trans-activation of the RAR $\beta_{2}$ promoter and that the AF- 2 of RXR $\alpha$ is not involved in trans-activation. A possible caveat is that the initial experiments were performed in the absence of the ligand for $R X R \alpha$. Furthermore, the LBD of RXR $\alpha$ was sensitive to limited protease digestion, suggesting that $\mathrm{RXR} \alpha$ was not in an activated status as observed with RAR $\alpha$. Therefore, we tested whether RXR $\alpha$ might contribute to the level of transcription when loaded with its respective ligand 9CRA (Heyman et al. 1992; Levin et al. 1992). RXR $\alpha / 6 \mathrm{H}-$ RAR $\alpha$ pretreated with 9C-RA elicited a level of transactivation indistinguishable from that obtained with T-RA pretreatment but significantly higher than that observed with untreated or DMSO-treated heterodimer (Fig. 6, lanes 2-12). A 10-fold lower concentration of 9C$\mathrm{RA}$ as compared with T-RA was required to obtain maximal trans-activation of the $\operatorname{RAR} \beta_{2}$ promoter in line with the results obtained with limited protease digestion experiments (see Fig. 2A). Further experiments clearly showed that the contribution of ligand-activated RXR $\alpha$
AF-2 was not simply masked in our in vitro transcription experiments by a strong AF- 2 of RAR $\alpha$. The RXR $\alpha / 6 \mathrm{H}-$ RAR $\alpha 390$ heterodimer lacking the AF- 2 of RAR $\alpha$ was unable to elicit trans-activation even after pretreatment with 9C-RA (data not shown). Furthermore, specific activation of the RAR $\alpha$ AF-2 in the heterodimer by the RAR $\alpha$-subtype-specific or RAR-specific synthetic agonists Ro 40-6055 and Ro 13-7410, respectively, elicited levels of transcription indistinguishable from those obtained with 9C-RA and T-RA (Fig. 6, lanes 13-19). The maximal level of trans-activation was already achieved at $400 \mathrm{~nm}$ of the synthetic agonist Ro 13-7410, although $\operatorname{RAR} \alpha$ has a threefold lower affinity for this analog as compared with T-RA or 9C-RA (Apfel et al. 1992).

\section{An RAR $\alpha$-specific antagonist abolishes trans-activation}

To strengthen our conclusion that in vitro transcription of the RAR $\beta_{2}$ promoter is ligand dependent, we used the RAR $\alpha$-specific antagonist Ro 41-5253 (Apfel et al. 1992). This compound has also been shown to induce a conformation distinct from that obtained with agonists (Keidel et al. 1994; data not shown). Pretreatment of the heterodimer with Ro 41-5253 abolished receptor-dependent trans-activation at $1 \mu \mathrm{M}$ Ro 41-5253 (Fig. 7A, cf. lane 2 with lanes $4-6$ ). The concentrations of the antagonist used in these experiments did not affect the ability of the heterodimer to bind to RARE $\beta_{2}$ (Fig. 7B). We conclude that the antagonist induced a conformational change in the LBD of RAR $\alpha$ distinct from that obtained with ago-

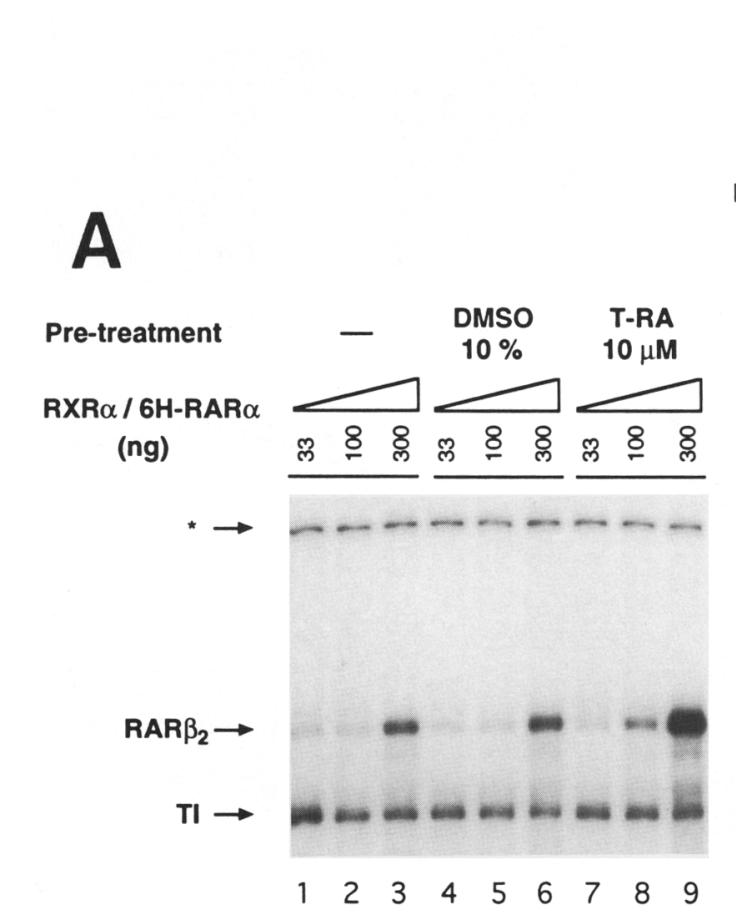

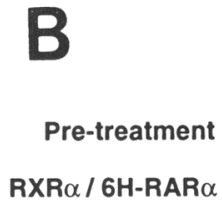

(ng)

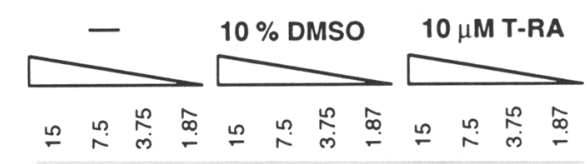

Figure 5. T-RA increases the trans-activation mediated by the heterodimer. $(A \mid \mathrm{T}$-RA effect on trans-activation in vitro. Amounts of template were $50 \mathrm{ng}$ of $T I$ and $25 \mathrm{ng}$ of RAR $\beta_{2}$ per reaction. The amount of heterodimer is indicated in nanograms. $(B)$ Effect of the T-RA in DNA binding. A ${ }^{32}$ p-labeled RARE $\beta_{2}$ oligonucleotide was used as a probe. The amount of heterodimer used is indicated in nanograms. 
Valcárcel et al.

Figure 6. Analysis of the concentration of T-RA, 9C-RA, or synthetic RAR-specific agonists (Ro 40-6055 and Ro 13-7410) required to achieve maximum trans-activation levels. The indicated amounts of agonists $(\mu \mathrm{M})$ in $10 \%$ DMSO were used in the pretreatments. Three hundred nanograms of heterodimer was added to the lanes labeled with $a+$. The amounts of template were $50 \mathrm{ng}$ of TI and $25 \mathrm{ng}$ of $\mathrm{RAR} \beta_{2}$ per reaction.

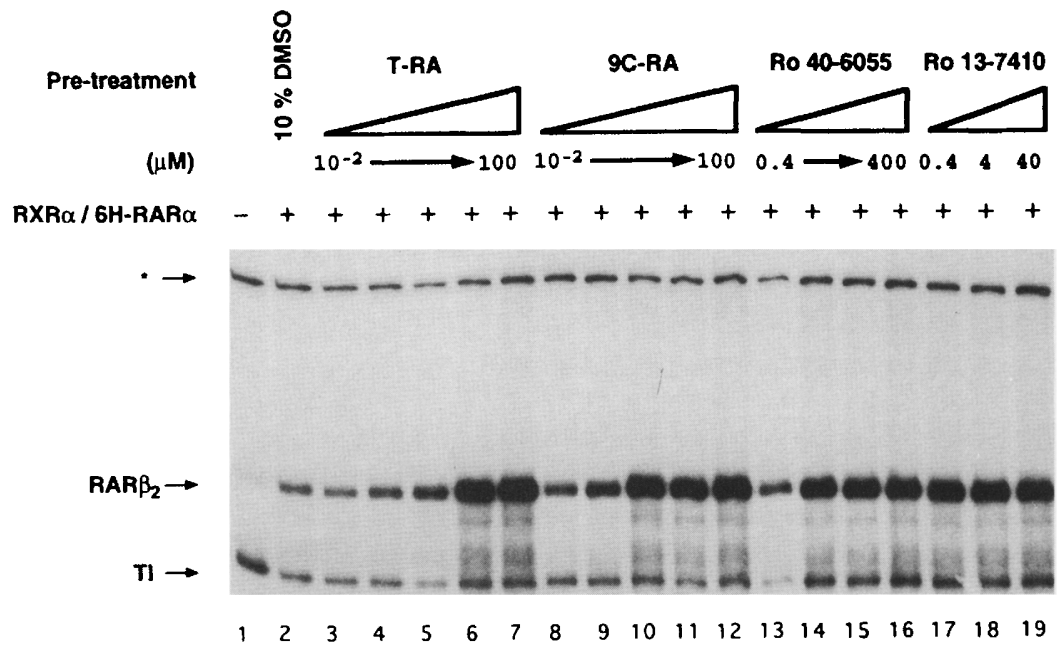

$\mathrm{RXR} \alpha / 6 \mathrm{H}-\mathrm{RAR} \alpha$ from the natural $\mathrm{RAR} \beta_{2}$ promoter in a cell-free system. The extracts used in our in vitro transcription assays consist of HeLa nuclear extract devoid of the phosphocellulose D-fraction complemented with a TFIID fraction from 293 cells (Graham and van der Eb 1973). RXR $\alpha / 6$ H-RAR $\alpha$ heterodimers are expressed in vaccinia virus-infected HeLa cells and highly enriched

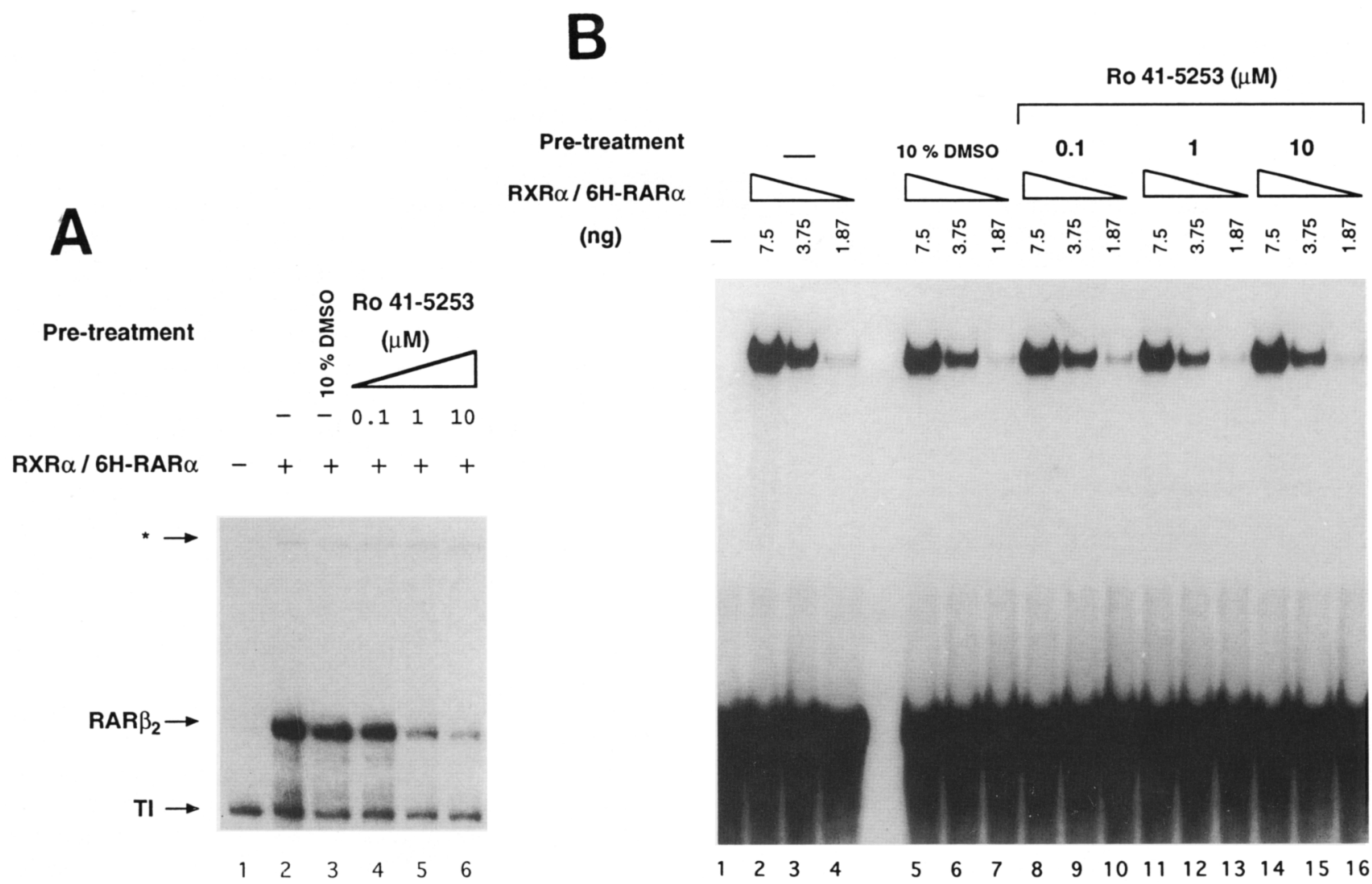

Figure 7. Antagonist pretreatment results in a transcriptionally inactive heterodimer. $(A)$ Effect of the antagonist in trans-activation in vitro. Three hundred nanograms of heterodimer was added to the lanes labeled with $\mathrm{a}+$. The pretreatments were carried in $10 \%$ DMSO. Amounts of template were $50 \mathrm{ng}$ of TI and $25 \mathrm{ng}$ of RAR $\beta_{2}$ per reaction. $(B)$ Effect of the antagonist on the ability of the heterodimer to bind DNA after pretreatment in $10 \%$ DMSO. A ${ }^{32} \mathrm{P}$-labeled RARE $\beta_{2}$ oligonucleotide was used as a probe. The amount of heterodimer used is indicated in nanograms. 
by $\mathrm{Ni}^{2+}-\mathrm{NTA}$ chromatography. At present, it cannot be excluded that the heterodimer preparation is "contaminated" with a putative coactivator as the heterodimer is produced in mammalian cells and not in bacteria. This could be attributable to sequestration of such a factor by the heterodimer. Alternatively, several factors have been cloned that contain a stretch of histidines and have an intrinsic ability to bind to the $\mathrm{Ni}^{2+}-\mathrm{NTA}$ column [e.g., TFIIA $\alpha / \beta$ (DeJong and Roeder 1993; Ma et al. 1993) and YY1 (Shi et al. 1991)]. However, such putative coactivators would be present in our HeLa nuclear extracts. Furthermore, control extracts derived from wild-type vaccinia virus-infected or mock-infected cells did not boost the level of transcription either from the RAR $\beta_{2}$ promoter or from the TI template.

Receptor-dependent trans-activation could be obtained with a promoter fragment comprising only the proximal RARE and TATA box. A cryptic, hitherto unidentified, RARE in the RAR $\beta_{2}$ promoter (position -83 to -67 ) boosted the level of transcription in vitro (Fig. 3B) and in vivo (B. Leblanc and H.G. Stunnenberg, in prep.). Pretreatment of the heterodimer with T-RA or 9C-RA boosted trans-activation to a level higher than that obtained with untreated or DMSO-treated heterodimer. Using truncated receptors, we could show that trans-activation by $\mathrm{RXR} \alpha / 6 \mathrm{H}-\mathrm{RAR} \alpha$ was fully dependent on an intact carboxy-terminal, ligand-dependent AF-2 of RAR $\alpha$. This notion is corroborated and extended by the finding that maximal levels of transcription were obtained by pretreatment with RAR-specific agonists only (i.e., in the absence of a ligand-activated RXR). The RAR-specific agonists Ro 40-6055 and Ro 13-7410 boosted trans-activation of the RAR $\beta_{2}$ promoter to a level equivalent to that obtained with T-RA. Preincubation of the heterodimer with 9C-RA, which binds both RAR $\alpha$ and RXR $\alpha$, did not yield a higher level of transcription as compared with T-RA or the RAR-specific agonists. The increased transcriptional activity of the heterodimer in response to agonist treatment parallels the increased resistance of RAR $\alpha$ to limited proteolysis (Fig. 2; Keidel et al. 1994), strongly suggesting that the ligand-induced conformational change in the LBD of RAR $\alpha$ exposes the transcriptional activation domain. Finally, incubation of the heterodimer with the RAR $\alpha$-specific antagonist resulted in a complete loss of transcriptional activity. One possible caveat could be that agonist treatment would promote solubilization (renaturation) of a partially aggregated heterodimer resulting in an apparent increase in the level of transcription. Extending this argument, antagonist treatment would then promote aggregation (denaturation). If this is the case, agonist/antagonist treatment should result in an increased/ decreased ability of the heterodimer to bind to the RARE $\beta_{2}$ oligonucleotide, which could not be observed. Furthermore, the conformational changes induced by both the agonist and the antagonist parallel the transcriptional activity of the receptors. Therefore, we conclude that ligand governs the transcriptional activity of recombinant RXR $\alpha /$ RAR $\alpha$.

Taken together, the data suggest that trans-activation of the RAR $\beta_{2}$ promoter by RXR $\alpha / 6 \mathrm{H}-\mathrm{RAR} \alpha$ in our reconstituted cell-free system required the presence of the AF- 2 activation function of RAR $\alpha$ and that the AF- 2 of RXR $\alpha$ did not contribute detectably to the level of transcription in vitro. These findings are in keeping with our in vivo cotransfection data showing that RAR $\alpha 390$, but not $\mathrm{RXR} \alpha 445$, acted as a dominant-negative receptor interfering with activation of the RAR $\beta_{2}$ promoter (D. Barettino, unpubl.). In line with our conclusions, it has been reported recently that in vivo a RXR-specific ligand had no effect on the transcriptional activation elicited by $\mathrm{RXR} \alpha / \mathrm{RAR} \alpha$, using a synthetic promoter that contains two DR5 elements, similar to the natural RAR $\beta_{2}$ promoter used in our study (Kurokawa et al. 1994). Thus, the major role of RXR $\alpha$ in trans-activation of the RAR $\beta_{2}$ promoter in vitro and in vivo is to serve as an auxiliary factor required for efficient DNA binding of RAR $\alpha$ to the RARE. The question arises whether RXR can act as a ligand-inducible transcription factor. If binding of the biologically active ligand 9C-RA to RXR yields a transcriptionally competent receptor, how can this be reconciled with its promiscuous role as an auxiliary factor required for trans-activation by RAR, thyroid hormone, vitamin $\mathrm{D}_{3}$, and other type II receptors? Transcriptional activation of RXR would inevitably elicit a pleiotropic but devastating effect because of the simultaneous activation of signaling pathways controlled by ligands that are physiologically unrelated to 9C-RA such as thyroid hormone and vitamin $D_{3}$. In the case of the RA-inducible RAR $\beta_{2}$ promoter, a contribution of 9C-RA-activated RXR to the level of transcription could have been envisioned easily, yet trans-activation appears to depend solely on ligandactivated RAR.

To explain the supraphysiological concentrations of ligands required in this in vitro system, two points should be considered: First, the concentration of heterodimer during the loading of the ligand was about $3 \mu \mathrm{m}$. Although moderate trans-activation could be obtained after pretreatment at concentrations as low as $10 \mathrm{nM} 9 \mathrm{C}$ $\mathrm{RA}$ and $100 \mathrm{nM}$ T-RA, maximal activation could only be achieved at 1 and $10 \mu \mathrm{M}$, respectively. Note that in the transcription reactions the final concentrations of the ligands required to obtain maximal activation were 30 and $300 \mathrm{~nm}$ for 9C-RA and T-RA, respectively. Second, in vivo, transport and delivery of retinoids are protein-mediated phenomena (Blomhoff et al. 1990) that may not have been mimicked in our in vitro system and that different ligands could have different accessibility to the receptors in vitro.

It should also be noted that the concentration of T-RA, 9C-RA, and the synthetic agonists required in the pretreatment to yield fully active receptor were not inversely proportional to the affinity of RAR $\alpha$ for that particular ligand. For example, although the dissociation constants for the binding of T-RA and 9C-RA to RAR $\alpha$ are equal $(0.2$ and $0.24 \mathrm{nM}$, respectively; Allenby et al. 1993), a 10-fold higher concentration of T-RA as compared with 9C-RA was required for full activation in our in vitro transcription assays. Using high pressure liquid chromatography separation of retinoids, we can exclude 
that T-RA becomes substantially isomerized during the pretreatment step (T. Houthaeve and C.G. Jiménez, unpubl.). More striking is the fact that as little as $400 \mathrm{~nm}$ of the synthetic agonist Ro 13-7410 was sufficient to obtain full trans-activation, although Ro 13-7410 has been reported to bind with a lower affinity to RAR $\alpha$ as compared with T-RA (Keidel et al. 1994). The antagonist Ro 41-5253 is more effective in inhibiting trans-activation in our in vitro transcription system than in preventing activation of RA-responsive genes in vivo as compared with the other ligands (Keidel et al. 1994). Taken together, these data indicate that the binding affinity is not the only parameter determining the potency of a given agonist or antagonist in exerting its function.

We provide the first biochemical evidence that the transcriptional activity of $\mathrm{RXR} \alpha / \mathrm{RAR} \alpha$ is governed by ligand and that this parallels with conformational changes in the receptors. Attempts to show similar effects with type I receptors in the past have yielded conflicting results. In vitro transcription assays using progesterone (PR) yielded ambiguous data. Receptor preparations from natural sources and loaded with the cognate ligand before extraction appeared to be somewhat more active in transcription assays than unliganded or antihormone-loaded receptors (Kalff et al. 1990; Bagchi et al. 1992), and recombinant PR receptor produced from a baculovirus vector was reported to activate transcription in vitro in a ligand-dependent fashion (Elliston et al. 1992). It should be noted that $P R$ requires ligand to bind DNA in vitro efficiently, which complicates an unambiguous assessment of the role of ligand in trans-activation (Bagchi et al. 1992). The level of transcription elicited by recombinant $P R$, glucocorticoid $(G R)$, estrogen (ER), and androgen (AR) was shown to be unaffected by addition of the cognate agonist or antagonist (Klein-Hitpass et al. 1990; Tsai et al. 1990; Shemschedini et al. 1992; Brou et al. 1993; Schmitt and Stunnenberg 1993; De Vos et al. 1994).

Ligand effects have been reported for type II receptors. Bacterially expressed $T_{3} R \alpha$ was shown to repress transcription from the growth hormone gene and other thyroid hormone response element (TRE)-containing promoters in vitro, and this repression could be alleviated by addition of $T_{3}$ (Fondell et al. 1993). The level of transcription elicited by baculovirus-expressed $T_{3} R \alpha-R X R \beta$ heterodimer was reported to be mostly ligand independent, although a modest activation could be obtained with addition of $T_{3}$ that could not be further enhanced by 9-C RA (Lee et al. 1994). The latter result seems to be in line with our conclusion that the major role of RXR is to serve as an auxiliary factor.

\section{Role of ligand}

In light of the observation that trans-activation by $\mathrm{RXR} \alpha / 6 \mathrm{H}-\mathrm{RAR} \alpha$ is fully dependent on the ligand-dependent AF-2 domain of RAR $\alpha$, it was surprising to find that recombinant heterodimer was partially active in the absence of exogenously added ligand. Because a small proportion of the recombinant receptor appeared to be resis- tant to protease digestion, it is possible that the recombinant receptors are partially loaded with ligand notwithstanding the fact that virus-infected cells were incubated in the absence of serum to minimize exposure to retinoids. Relatively high amounts of ligand could, however, be present within the cell bound to cellular retinoic acid-binding proteins (CRABPs) (Blomhoff et al. 1990). Although this possibility cannot be excluded at present, we suggest the following model: In vivo, the ligand-binding domain of RAR is highly disordered in the absence of ligand and, hence, very sensitive to protease digestion. The trans-activation function is either not exposed on the surface of the ligand-binding domain or is masked by a repressor. At present, it cannot be ruled out that in vivo the RAR and RXR are monomeric in the absence of ligand and that ligand plays a role in dimerization and, hence, affects partner selection (Zhang et al. 1992; Thomas et al. 1993; Yao et al. 1993). In line with such a scenario is the finding by Ozato and co-workers that RXR/RAR is not occupying the RARE in the RAR $\beta_{2}$ promoter in the absence of ligand as revealed by in vivo footprint experiments (Minucci et al. 1994). In vaccinia virus-infected cells, where recombinant RXR and RAR are made, the receptors might be in a "transition" state that is characterized by a more compact folding of the LBD and, hence, RXR and RAR form "stable" heterodimers. In this state, the AF-2 can display low transcriptional activity although the ligand pocket is still disordered in the absence of ligand. This transition state might be attributable to a viral infection-linked modification of the receptor such as phosphorylation.

Agonist treatment of vaccinia virus-expressed heterodimer induces a very compact folding by ordering residues in the ligand pocket and, consequently, the LBD is insensitive to protease digestion. Thus, the AF- 2 in the LBD is in a fully transcriptionally active state, optimally displaying the surface for interaction with the basal transcriptional machinery or presumed coactivators. Addition of DMSO or ethanol in the pretreatment step might be important to obtain efficient ligand binding. These solvents may allow exposure of hydrophobic residues, thereby facilitating entry of the ligand into a hydrophobic pocket. Presumably, ligand-receptor interactions are of the "induced fit" type, as postulated for avidin-biotin, where residues that are disordered in the free protein are ordered with binding of biotin enclosing this ligand in a "hydrophobic box" (Livnah et al. 1993).

In previous studies we have postulated that RAR/RXR can activate the RAR $\beta_{2}$ promoter by two different signaling routes: a "default" pathway used in differentiated cells and a "super-activation" pathway that seems to be restricted to embryonal cells. Superactivation can be mimicked in non-embryonic carcinoma (EC) cells by cotransfection of the TATA-binding protein (TBP), along with the adenovirus ElA $_{13 \text { s }}$ protein (Berkenstam et al. 1992; Keaveney et al. 1993). The extracts used in our in vitro transcription assays consist of a HeLa extract devoid of the phosphocellulose D-fraction complemented with a TFIID fraction from 293 cells that are transformed with E1A and E1B (Graham and van der Eb 1973). At 
present, it is unclear whether trans-activation signaling in our cell-free system occurs by the default or superactivation pathway. Experiments are in progress to assess the potential role of ElA or the cellular ElA-like activity in the activation of the $R A R \beta_{2}$ promoter.

\section{Materials and methods}

\section{Recombinant vaccinia viruses}

Recombinant vaccinia viruses expressing 6H-RAR $\alpha, 6 \mathrm{H}-\mathrm{RXR} \alpha$, and $\mathrm{RXR} \alpha$ were prepared as described (Stunnenberg et al. 1988. Bugge et al. 1992; Schmitt and Stunnenberg 1993). 6HRAR $\alpha 19$ and $6 \mathrm{H}-\mathrm{RAR} \alpha 390$ were constructed by introducing stop codons at positions 420 and 391 , respectively, using PCR. $6 \mathrm{H}-\mathrm{RXR} \alpha$ was obtained by subcloning the human $\mathrm{RXR} \alpha \mathrm{cDNA}$ into pMS56 (Janknecht et al. 1991). The amino acids -MSHHHHHHGEF- precede the second amino acid of human RXR $\alpha$. RXR $\alpha 445$ was constructed by inserting a PCR fragment with a stop codon at amino acid position 446 into pSG5. A fragment of RXR $\alpha 445$ was then subcloned into a pATA-18-derived plasmid (Stunnenberg et al. 1988) to obtain pATA-RXR $\alpha 445$.

\section{Transcription templates}

The RAR $\beta_{2}[380]$ G-less construct contains the RAR $\beta_{2}$ promoter from sequence -124 to -21 as described (Berkenstam et al. 1992) in front of a G-less cassette (Sawadogo and Sentenac 1990). The TI[320] G-less construct used as an internal control is described in Pugh and Tjian (1990). The G-less reporter plasmids containing the TATA box mutations -TGTAAAA-, -TATAAAA-, and -TATATTA- were obtained by subcloning $X b a I$ fragments, including the promoter from the $\mathrm{Ml}, \mathrm{M} 2$, and M4 mutants (Berkenstam et al. 1992; Keaveney et al. 1993) into the EcoRV site of the $\mathrm{p}\left(\mathrm{C}_{2} \mathrm{AT}\right)[380]-\mathrm{G}$-less vector (Monaci et al. 1988). The promoter fragment differs from the natural RAR $\beta_{2}$ promoter also at position $-32(\mathrm{C} \rightarrow \mathrm{A})$. The $\mathrm{m} 3, \mathrm{~m} 7$ (Vivanco Ruiz et al. 1991), and TAGAGAA (Berkenstam et al. 1992) mutants were used to obtain PCR fragments that were inserted

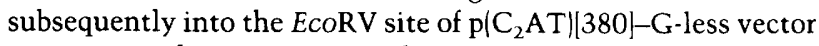
to generate the m3-, m7-, and TAGAGAA-G-less templates. Mutations $m 3$ and $m 7$ affect the proximal RARE of the RAR $\beta_{2}$ promoter GGTTCACCGAAAGTTCA (position -53 to -51 to $A A C$ and -41 to -39 to TCG, respectively). The RAR $\beta_{2} \Delta$ upsm3-ups-, and m7-ups-G-less mutants were obtained by deleting the fragment from -124 to -59 corresponding to the natural $\mathrm{RAR} \beta_{2}$ promoter.

\section{Receptor purifications}

Preparation of nuclear extracts from virus-infected cells was performed as described (Vivanco Ruiz et al. 1991). Receptor purifications by $\mathrm{Ni}^{2+}$-NTA chromatography were done essentially as described (Schmitt et al. 1993), using buffer D [20 mM HEPES (pH 7.9), $5 \mathrm{~mm} \mathrm{MgCl} 2,0.1 \mathrm{~mm}$ EDTA, I mM DTT, $10 \mathrm{~mm}$ $\mathrm{NaF}, 0.1 \mathrm{mM}$ PMSF, $20 \%$ glycerol, and $0.1 \%$ Triton X-100] supplemented with $100 \mathrm{~mm} \mathrm{NaCl}$. Western blotting using polyclonal antibodies directed against the LBD of RAR $\alpha$ and RXR $\alpha$ and mobility-shift assays, which were carried out as described previously (Bugge et al. 1992), were used to follow the purification of the receptors.

DNA affinity purification was performed as follows: A double-stranded DNA fragment containing the RARE $(D R+5)$ from the $\mathrm{RAR} \beta_{2}$ promoter (position -60 to -32 ) extended with two biotinylated carboxyl residues was bound to streptavidin-coated paramagnetic beads as recommended by the manufacturer
(Dynal). $\mathrm{Ni}^{2+}$-NTA-purified receptors were added to the magnetic beads and incubated for $30 \mathrm{~min}$ at $4^{\circ} \mathrm{C}$. The beads were washed twice with five volumes of buffer D50 (D with $50 \mathrm{~mm}$ $\mathrm{NaCl}$ ) and twice with D250. Bound receptors were eluted with five bead volumes of D1000. Western blotting, mobility-shift assays, and silver nitrate staining were used to determine their purity and quantity. The purity of the various receptor preparations was estimated by silver nitrate staining. Figure 1 shows an example with $\mathrm{Ni}^{+}-\mathrm{NTA}$-purified heterodimer and $>80 \%$ purity was achieved when DNA affinity chromatography was carried out as well (data not shown). DNA affinity-purified receptors were used for the experiments presented in Figure 4 and the rest of the experiments were performed using $\mathrm{Ni}^{2+}-\mathrm{NTA}$ purified receptors. All purified receptors were quick-frozen in liquid nitrogen and stored at $-80^{\circ} \mathrm{C}$.

\section{In vitro transcription assays}

Nuclear extracts were prepared from HeLa S3 and 293 cells and chromatographed on phosphocellulose columns as described (Berkenstam et al. 1992). Thirty liters of HeLa cells was used for preparing the nuclear extract that was dialyzed to adjust the $\mathrm{KCl}$ concentration to $500 \mathrm{mM}$ and loaded on a phosphocellulose column as described (Berkenstam et al. 1992). The $500 \mathrm{~mm} \mathrm{KCl}$ HeLa fraction was used as a source of general factors (with a protein concentration of $8 \mathrm{mg} / \mathrm{ml}$ as determined by the Bradford method). One hundred liters of 293 cells was used to prepare a nuclear extract that was adjusted to a $\mathrm{KCl}$ concentration of 100 $\mathrm{mM}$ and loaded on a Whatman P11 phosphocellulose column (1 $\mathrm{ml}$ of packed cell volume per milliliter of packed phosphocellulose) equilibrated in $20 \mathrm{~mm}$ HEPES-KOH $(\mathrm{pH} 7.8 \mid, 20 \%$ glyc erol, $10 \mu \mathrm{M} \mathrm{ZnCl}_{2}, 10 \mathrm{~mm} 2$-mercaptoethanol, and $100 \mathrm{~mm} \mathrm{KCl}$. The fraction eluted at $750 \mathrm{mM} \mathrm{KCl}$ / with a protein concentration of $1.5 \mathrm{mg} / \mathrm{ml}$ as determined by the Bradford method!, containing TFIID, was used for complementing the $500 \mathrm{mM} \mathrm{KCl}$ $\mathrm{HeLa}$ fraction in the in vitro transcription reactions.

Transcription assays contained $20 \mathrm{~mm}$ HEPES (pH 7.9), $6 \mathrm{~mm}$ $\mathrm{MgCl}_{2}, 70 \mathrm{~mm} \mathrm{KCl}, 0.2 \mathrm{~mm}$ EDTA, $1 \mathrm{~mm}$ DTT, $7.5 \%$ glycerol, $2.5 \%$ polyethylene glycol $6000,10 \mathrm{~mm}$ creatine phosphate, $1 \mu \mathrm{g}$ of calf thymus DNA, 70 units of RNase Tl (Sigma), 10-50 ng of each template $(\sim 10-50$ fmoles $), 0.6 \mathrm{~mm} \mathrm{ATP}, 0.6 \mathrm{~mm}$ CTP, 20 $\mu \mathrm{M}$ UTP, $0.5 \mathrm{~mm} \mathrm{3'-O}$ methyl GTP (Pharmacia), and $0.4 \mu \mathrm{M}$ $\left[\alpha^{-32} \mathrm{P}\right] U T P(800 \mathrm{Ci} / \mathrm{mmole}$; Amersham) in a final volume of 30 $\mu$ l. Fifteen to $30 \mu \mathrm{g}$ of the $500 \mathrm{mM} \mathrm{KCl} \mathrm{HeLa}$ fraction and 2 to 4 $\mu \mathrm{g}$ of the $750 \mathrm{~mm} \mathrm{KCl} 293$ fraction were used per reaction. Pretreatment of receptors with ligands or solvent alone $110 \%$ DMSO final concentration/ involved incubation of aliquots of receptor ( $3 \mu \mathrm{M}$ final concentration) with 0.1 volume of ligand (in $100 \%$ DMSO/ for $20 \mathrm{~min}$ at room temperature in siliconized tubes.

Transcription reaction mixtures were preincubated at $30^{\circ} \mathrm{C}$ for $30 \mathrm{~min}$ in the absence of nucleotides. Transcription was initiated by the addition of nucleotides, followed by an incubation for $\mathrm{l} \mathrm{hr}$ at $30^{\circ} \mathrm{C}$. Reactions were terminated by the addition of $180 \mu \mathrm{l}$ of stop mix $[0.1 \mathrm{~m}$ sodium acetate $(\mathrm{pH} 5.2), 10 \mathrm{~mm}$ EDTA, $0.1 \%$ SDS, $60 \mu \mathrm{g} / \mathrm{ml}$ of tRNA] containing $\sim 300 \mathrm{cpm}$ of a $600-b p{ }^{32}$ P-labeled DNA fragment, followed by phenol-chloroform-isoamyl alcohol $(25: 25: 1)$ extraction and isopropanol precipitation. RNA products were separated on $6 \%$ polyacrylamide sequencing gels, dried, and autoradiographied for $24-48$ hr at $-80^{\circ} \mathrm{C}$ with an intensifying screen.

\section{Limited proteolytic digestion}

Receptors $(1.2 \mu \mathrm{g})$ were incubated with the proteases and retinoids in siliconized tubes in a final volume of $10 \mu \mathrm{l}$ as described 
(Keidel et al. 1994). Proteolytic products were analyzed by Western blotting using polyclonal antibodies directed against the human RAR $\alpha$ LBD (amino acids 152 to 419 ) and RXR $\alpha$ LBD (amino acids 204-462) (I. Pohl and H.G. Stunnenberg, unpubl.). Horseradish peroxidase-linked anti-rabbit inmunoglobulin was used as the second antibody, and protein-antibody complexes were visualized by an enhanced chemiluminescence Western blotting detection system according to the recommendations of the manufacturer (Amersham).

\section{Acknowledgments}

We thank Vera Sonntag-Buck for excellent technical assistance in tissue culture and Jens Pohl for the polyclonal antibodies. We are grateful to our colleagues Iain Mattaj, Peter Becker, Hans Schöler, Francis Stewart, and members of the Stunnenberg group for critical reading of the manuscript and discussion. We thank Christian Apfel (Hoffmann-La Roche Ltd.) for providing synthetic retinoids and for performing ligand binding assays, and Tony Houthaeve for his help with HPLC analysis. R.V. was supported by an European Molecular Biology Organization fellowship, C.G.J. by a fellowship from the Ministry of Education and Science (Spain), and D.B. by a fellowship from the Commission of the European Communities.

The publication costs of this article were defrayed in part by payment of page charges. This article must therefore be hereby marked "advertisement" in accordance with 18 USC section 1734 solely to indicate this fact.

\section{References}

Allan, G.F., S.Y. Tsai, M.J. Tsai, and B.W. O'Malley. 1992. Ligand-dependent conformational changes in the progesterone receptor are necessary for events that follow DNA binding. Proc. Natl. Acad. Sci. 89: 11750-1754.

Allenby, G., M.T. Bocquel, M. Saunders, S. Kazmer, J. Speck, M. Rosenberger, A. Levoy, P. Kastner, J.F. Grippo, and P. Chambon. 1993. Retinoic acid receptors and retinoid X receptors: Interactions with endogenous retinoic acids. Proc. Natl. Acad. Sci. 90: 30-34.

Apfel, C., F. Bauer, M. Crettaz, L. Forni, M. Kamber, F. Kaufmann, P. LeMotte, W. Pirson, and M. Klaus. 1992. A retinoic acid receptor alpha antagonist selectively counteracts retinoic acid effects. Proc. Natl. Acad. Sci. 89: 71297133.

Bagchi, M.K., S.Y. Tsai, M.-J. Tsai, and B.W.O. O'Malley. 1992. Ligand and DNA-dependent phosphorylation of human progesterone receptor in vitro. Proc. Natl. Acad. Sci. 89: 2664 2668 .

Berkenstam, A., M.D.M. Vivanco Ruiz, D. Barettino, M. Horikoshi, and H.G. Stunnenberg. 1992. Cooperativity in transactivation between retinoic acid receptor and TFIID requires an activity analogous to E1A. Cell 69: 401-412.

Blomhoff, R., M.H. Green, T. Berg, and K.R. Norum. 1990. Transport and storage of vitamin A. Science 250: 399-404.

Brou, C., J. Wu, S. Ali, E. Scheer, C. Lang, I. Davidson, P. Chambon, and L. Tora. 1993. Different TBP-associated factors are required for mediating the stimulation of transcription in vitro by the acidic transactivator GAL-VP16 and the two nonacidic activation functions of the estrogen receptor. $\mathrm{Nu}$ cleic Acids Res. 21: 5-12.

Bugge, T.H., J. Pohl, O. Lonnoy, and H.G. Stunnenberg. 1992. RXR alpha, a promiscuous partner of retinoic acid and thyroid hormone receptors. EMBO I. 11: 1409-1418.

Chambon, P. 1994. The retinoid signalling pathway: Molecular and genetic analyses. Semin. Cell Biol. 5: 115-125.

DeJong, J. and R.G. Roeder. 1993. A single cDNA, hTFIIA/ $\alpha$, encodes both the p35 and p19 subunits of human TFIIA. Genes \& Dev. 7: 2220-2234.

De Luca, L.M. 1991. Retinoids and their receptors in differentiation, embryogenesis, and neoplasia. FASEB I. 5: 2924-2933.

De Thé, H., M.D.M. Vivanco Ruiz, P. Tiollais, H. Stunnenberg, and A. Dejean. 1990. Identification of a retinoic acid responsive element in the retinoic acid receptor $\beta$ gene. Nature 343: $177-180$.

De Vos, P., J. Schmitt, G. Verhoeven, and H.G. Stunnenberg. 1994. Human androgen receptor expressed in HeLa cells activates transcription in vitro. Nucleic Acids Res. 22: 11611166.

Durand, B., M. Saunders, P. Leroy, M. Leid, and P. Chambon. 1992. All-trans and 9-cis retinoic acid induction of CRABPII transcription is mediated by RAR-RXR heterodimers bound to DR1 and DR2 repeated motifs. Cell 71: 73-85.

Elliston, J.F., J.M. Beekman, S.Y. Tsai, B.W. O'Malley, and M.-J. Tsai. 1992. Hormone activation of baculovirus expressed progesterone receptors. J. Biol. Chem. 267: 5193-5198.

Folkers, G.E., B.J. Van der Leede, and P.T. Van der Saag. 1993. The retinoic acid receptor-beta 2 contains two separate cellspecific transactivation domains, at the $\mathrm{N}$-terminus and in the ligand-binding domain. Mol. Endocrinol. 7:616-627.

Fondell, J.D., A.L. Roy, and R.G. Roeder. 1993. Unliganded thyroid hormone receptor inhibits formation of a functional preinitiation complex: Implications for active repression. Genes \& Dev. 7: 1400-1410.

Graham, F.L. and A.J. van der Eb. 1973. A new technique for the assay of infectivity of human adenovirus DNA. Virology 52: $456-467$.

Heyman, R.A., D.J. Mangelsdorf, J.A. Dyck, R. Stein, G. Eichele, R.M. Evans, and C. Thaller. 1992. 9-Cis retinoic acid is a high affinity ligand for the retinoid X receptor. Cell 68: 397406 .

Janknecht, R., G. De Martynoff, J. Lou, R.A. Hipskind, A. Nordheim, and H.G. Stunnenberg. 1991. Rapid and efficient purification of native histidine-tagged protein expressed by recombinant vaccinia virus. Proc. Natl. Acad. Sci. 88: 89728976.

Kalff, M., B. Gross, and M. Beato. 1990. Progesterone receptor stimulates transcription of mouse mammary tumor virus in a cell-free system. Nature 344: 360-362.

Keaveney, M., A. Berkenstam, M. Feigenbutz, G. Vriend, and H.G. Stunnenberg. 1993. Residues in the TATA-binding protein required to mediate a transcriptional response to retinoic acid in EC cells. Nature 365: 562-566.

Keidel, S., P. LeMotte, and C. Apfel. 1994. Different agonist- and antagonist-induced conformational changes in retinoic acid receptors analyzed by protease mapping. Mol. Cell. Biol. 14: 287-298.

Klein-Hitpass, L., S.Y. Tsai, N.L. Weigel, G.F. Allan, D. Riley, R. Rodriguez, W.T. Schrader, M.-J. Tsai, and B.W. O'Malley. 1990. The progesterone receptor stimulates cell-free transcription by enhancing the formation of a stable preinitiation complex. Cell 60: 247-257.

Kliewer, S.A., K. Umesono, D.J. Mangelsdorf, and R.M. Evans. 1992a. Retinoid X receptor interacts with nuclear receptors in retinoic acid, thyroid hormone and vitamin $\mathrm{D}_{3}$ signalling. Nature 355: 446-449.

Kliewer, S.A., K. Umesono, D.J. Noonan, R.A. Heyman, and R.M. Evans. 1992b. Convergence of 9-cis retinoic acid and peroxisome proliferator signalling pathways through heterodimer formation of their receptors. Nature 358: 771-774.

Kurokawa, R., J. DiRenzo, M. Boehm, J. Sugarman, B. Gloss, M.G. Rosenfeld, R.A. Heyman, and C.K. Glass. 1994. Regulation of retinoid signalling by receptor polarity and allos- 
teric control of ligand binding. Nature 371: 528-531.

Kurokawa, R., V.C. Yu, A. Naar, S. Kyakumoto, Z. Han, S. Silverman, M.G. Rosenfeld, and C.K. Glass. 1993. Differential orientations of the DNA-binding domain and carboxy-terminal dimerization interface regulate binding site selection by nuclear receptor heterodimers. Genes \& Dev. 7: 1423-1435.

Lee, I.J., P.H. Driggers, J.A. Medin, V.M. Nikodem, and K. Ozato. 1994. Recombinant thyroid hormone receptor and retinoid $\mathrm{X}$ receptor stimulate ligand-dependent transcription in vitro. Proc. Natl. Acad. Sci. 91: 1647-1651.

Leid, M. 1994. Ligand-induced alteration of the protease sensitivity of retinoid X receptor $\alpha$. J. Biol. Chem. 269: 1417514181

Leid, M., P. Kastner, and P. Chambon. 1992a. Multiplicity generates diversity in the retinoic acid signalling pathways. Trends Biochem. 17: 427-433.

Leid, M., P. Kastner, R. Lyons, H. Nakshatri, M. Saunders, T. Zacharewski, J.-Y. Chen, A. Staub, J.-M. Garnier, S. Mader, and P. Chambon. 1992b. Purification, cloning, and RXR identity of a HeLa cell factor with which RAR or TR heterodimerizes to bind target sequences efficiently. Cell 68: 377-395.

Levin, A.A., L.J. Sturzenbecker, S. Kazmer, T. Bosakowski, C. Huselton, G. Allenby, J. Speck, C. Kratzeisen, M. Rosenberger, A. Lovey, and J.F. Grippo. 1992. 9-Cis retinoic acid stereoisomer binds and activates the nuclear receptor RXR alpha. Nature 355: 359-361.

Livnah, O., E.A. Bayer, M. Wilchek, and J.L. Sussman. 1993. Three-dimensional structures of avidin and the avidin-biotin complex. Proc. Natl. Acad. Sci. 90: 5076-5080.

Ma, M., H. Watanabe, F. Mermelstein, A. Admon, K. Oguri, X. Sun, T. Wada, T. Imai, T. Shiroya, D. Reinberg, and H. Handa. 1993. Isolation of a cDNA encoding the largest subunit of TFIIA reveals functions important for activated transcription. Genes \& Dev. 7: 2246-2257.

Mangelsdorf, D.J., K. Umesono, S.A. Kliewer, U. Borgmeyer, E.S. Ong, and R.M. Evans. 1991. A direct repeat in the cellular retinol-binding protein type II gene confers differential regulation by RXR and RAR. Cell 66: $555-561$.

Marks, M.S., P.L. Hallenbeck, T. Nagata, J.H. Segars, E. Appella, V.M. Nikodem, and K. Ozato. 1992. H-2RIIBP (RXRß) heterodimerization provides a mechanism for combinatorial diversity in the regulation of retinoic acid and thyroid hormone responsive genes. EMBO I. 11: 1419-1435.

Minucci, S., D.J. Zand, A. Dey, M.S. Marks, T. Nagata, J.F. Grippo, and K. Ozato. 1994. Dominant negative retinoid X receptor beta inhibits retinoic acid-responsive gene regulation in embryonal carcinoma cells. Mol. Cell. Biol. 14: 360372.

Monaci, P., A. Nicosia, and R. Cortese. 1988. Two different liver-specific factors stimulate in vitro transcription from the human $\alpha 1$-antitrypsin promoter. EMBO I. 7: 2075-2087.

Nagpal, S., M. Saunders, P. Kastner, B. Durand, H. Nakshatri, and P. Chambon. 1992. Promoter context- and response element-dependent specificity of the transcriptional activation and modulating functions of retinoic acid receptors. Cell 70: 1007-1019.

Nagpal, S., S. Friant, H. Nakshatri, and P. Chambon. 1993. RARs and RXRs: Evidence for two autonomous transactivation functions (AF-1 and AF-2) and heterodimerization in vivo. $E M B O$ I. 12: 2349-2360.

Perlmann, T., P.N. Rangarajan, K. Umesono, and R.M. Evans. 1993. Determinants for selective RAR and TR recognition of direct repeat HREs. Genes \& Dev. 7: 1411-1422.

Pugh, B.F. and R. Tjian. 1990. Mechanism of transcriptional activation by $\mathrm{Sp1}$ : Evidence for coactivators. Cell 61: 1187-
1197.

Sawadogo, M. and A. Sentenac. 1990. RNA polymerase B (II) and general transcription factors. Annu. Rev. Biochem. 59: 711754.

Schmitt, J. and H.G. Stunnenberg. 1993. The glucocorticoid receptor hormone binding domain mediates transcriptional activation in vitro in the absence of ligand. Nucleic Acids Res. 21: 2673-2681.

Schmitt, J., H. Hess, and H.G. Stunnenberg. 1993. Affinity purification of histidine-tagged proteins. Mol. Biol. Rep. 18: 18.

Shemschedini, L., J. Ji, C. Brou, P. Chambon, and H. Gronemeyer. 1992. In vitro activity of the transcription activation functions of the progesterone receptor. I. Biol. Chem. 267: 1834-1839.

Shi, Y., E. Seto, L.S. Chang, and T. Shenk. 1991. Transcriptional repression by YYl, a human GLI-krupple related protein, and relief of repression by adenovirus Ela protein. Cell 67: $377-388$.

Strubin, M. and K. Struhl. 1992. Yeast and human TFIID with altered DNA-binding specificity for TATA elements. Cell 68: $721-730$.

Stunnenberg, H.G. 1993. Mechanisms of transactivation by retinoic acid receptors. BioEssays 15: 309-315.

Stunnenberg, H., H. Lange, L. Philipson, R.T. van Miltenburg and P.C. van der Vliet. 1988. High expression of functional adenovirus DNA polymerase and precursor terminal protein using recombinant vaccinia vinus. Nucleic Acids Res. 16: $2431-2444$.

Sucov, H.M., K.K. Murakami, and R.M. Evans. 1990. Characterization of an autoregulated response element in the mouse retinoic acid receptor type $\beta$ gene. Proc. Natl. Acad. Sci. 87: 5392-5396.

Thomas, H.E., H.G. Stunnenberg, and A.F. Stewart. 1993. Heterodimerisation of the Drosophila ecdysone receptor with retinoid $X$ receptor and Ultraspiracle. Nature 362: 471-475.

Tsai, S.Y., G. Scrinivasan, G.A. Allan, E.B. Thompson, B.W O'Malley, and M.-J. Tsai. 1990. Recombinant human glucocorticoid receptor induces transcription of hormone response genes in vitro. J. Biol. Chem. 265: 17055-17061.

Vivanco Ruiz, M.D.M., T. Bugge, P. Hirschmann, and H.G. Stunnenberg. 1991. Functional characterization of a natural element for retinoic acid. EMBO I. 10: 3829-3838.

Yao, T.P., B.M. Forman, Z. Jiang, L. Cherbas, J.D. Chen, M. Mckeown, P. Cherbas, and R.M. Evans. 1993. Functional ecdysone receptor is the product of EcR and Ultraspiracle genes. Nature 366: 476-479.

Yu, V.C., C. Delsert, B. Andersen, J.M. Holloway, O.M. Devary, A.M. Näär, S.Y. Kim, J.-M. Boutin, C.K. Glass, and M.G. Rosenfeld. 1991. RXR $\beta$ : A coregulator that enhances binding of retinoic acid, thyroid hormone and vitamin $D$ receptors to their cognate response elements. Cell 67: 1251-1266.

Zechel, C., X.-Q. Shen, P. Chambon, and H. Gronemeyer. 1994a. Dimerization interfaces formed between the DNA binding domains determine the cooperative binding of RXR/ RAR and RXR/TR heterodimers to DR5 and DR4 elements. EMBO I. 13: 1414-1424

Zechel, C., X.-Q. Shen, J.-Y. Chen, Z.-P. Chen, P. Chambon, and H. Gronemeyer 1994b. The dimerization interfaces formed between the DNA binding domains of RXR, RAR and TR determine the binding specificity and polarity of the fulllength receptors to direct repeats. EMBO /. 13:1425-1433.

Zhang, X., J. Lehmann, B. Hoffmann, M.I. Dawson, J. Cameron, G. Graupner, T. Hermann, P. Tran, and M. Pfahl. 1992. Homodimer formation of retinoid $\mathrm{X}$ receptor induced by 9 -cis retinoic acid. Nature 358: 587-591. 


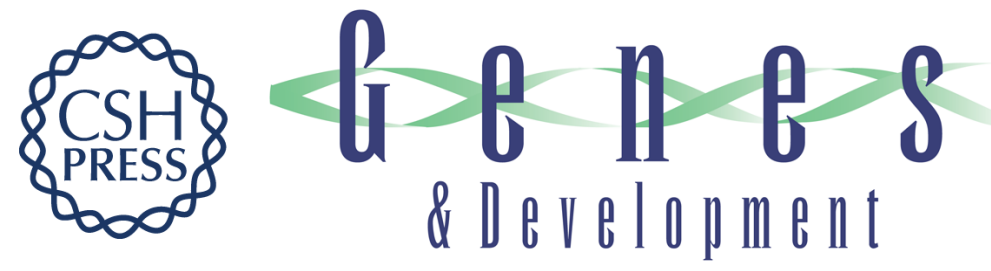

\section{Retinoid-dependent in vitro transcription mediated by the RXR/RAR heterodimer.}

R Valcárcel, H Holz, C G Jiménez, et al.

Genes Dev. 1994, 8:

Access the most recent version at doi:10.1101/gad.8.24.3068

References This article cites 60 articles, 20 of which can be accessed free at:

http://genesdev.cshlp.org/content/8/24/3068.full.html\#ref-list-1

License

Email Alerting

Service

Receive free email alerts when new articles cite this article - sign up in the box at the top right corner of the article or click here.

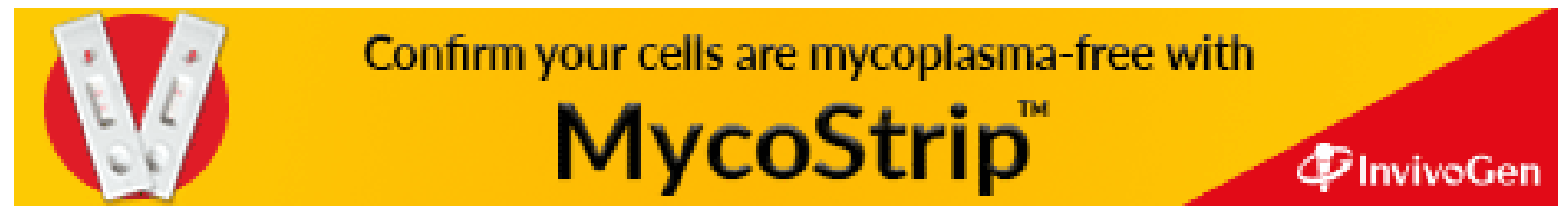

